\title{
Multi-Criteria Assessment of Vegetable Production Business Alternatives
}

\author{
Silvo Pozderec, Martina Bavec, Črtomir Rozman, Jožef Vinčec, Karmen Pažek
}

\author{
University of Maribor, Faculty of Agriculture and Life Sciences, Pivola 10, 2311 Hoče, Slovenia. \\ Corresponding author: karmen.pazek@um.si
}

Purpose: Organic and integrated production of vegetables are the two most common production systems in Slovenia. The study analyzed two production systems with different cultures as alternatives with purpose to find the most appropriate variants.

Design/Methodology/Approach: The study based on the development and integration of developed specific technological-economic simulation models for the production of vegetables (salad, growing peppers, salad cucumbers, pickling cucumbers, round and cherry tomato) in greenhouse and multi-criteria decision analysis. The methodology of the study based on the DEX methodology and the analytical hierarchy process (AHP) of organic (ECO) and integrated production (IP) in greenhouse.

Results: The evaluation results show that both cultivation methods of commercially attractive vegetables in greenhouse are variable. In the case of integrated production, the assessment of multi-criteria decision analysis EC and DEXi showed that salad (Donertie F1) proved to be the best possible alternative. In the case of organic production, the multi-criteria analysis assessment of pickling cucumbers (Harmony F1) is the best possible business alternative. Conclusion: For the further production planning process by decision maker is the ranking with Expert Choice (EC) more useful and precise, while the DEX evaluations are more descriptive.

Keywords: simulation model; multi-criteria analysis; vegetable; greenhouse

\section{Introduction}

Integrated decision support systems and costs studies for the cultivation of commercially attractive vegetables in greenhouse are not sufficiently explored, as can be seen from domestic and foreign literature. The preliminary information about expected costs and returns of the vegetable production in greenhouse is essential for further planning and conducting investments in greenhouses and the production of market-attractive vegetables in greenhouse.

Based on a study of simulation models and the MCDA method carried out by Klajić (2000) and Škraba (2003), it is assumed that simulation modelling combined with MCDA methods could be useful applied for vegetable production decision support. In the field crop production, the modeling of sugar beet and its processing into sugar for purpose of decision support is presented by Rozman et al. (2014). The analysis system dynamics methodology was chosen to model impacts of regional sugar factory investment. Fur- ther, the model for decision - making in agriculture is presented by Cardin-Pedrosa and Alvarez-López (2012). The authors explain the process followed to generate the model used as a decision support tool for agricultural production planning in the most agrarian areas in Galicia.

The model includes social, environmental and economic indicators developed using both monographic information and field data. Hayashi (2000) combined in agricultural resource management multi-attribute utility theory and goal programming method for solving multi-objective planning problems. The optimal input use condition in agricultural sector (water irrigation) is evaluating by multi-attribute utility and multi-attribute marginal utility by Gómez-Limón et al. (2004) and Riesgo and Gomez-Limon (2006).

The similar problem is observed by Latinopoulos (2009). Pavlovič et al. (2011) emphasize the support by expert decisions for selection of hybrids in agriculture. The authors expose the amount of available data and the meth- 
ods for describing performance of an individual cultivar. The data summarization process is often the major limitation associated with producers making a good decision. In this way, the AHP can be applied for assessing multifunctional performances of different agricultural systems in a comparative way to other multifunctional economic activities. Parra-López et al. (2007) compare the multifunctional performance of alternative olive growing systems in Andalusia on the basis of the assessments of different groups of experts.

Some examples of using the multi-criteria decision analysis for evaluation or classification of the most suitable sorts or cultivars can be found in literature (Bohanec et al., 2008, Jayakumar and Hari Ganesh, 2012, Mohamed et al., 2012, Dragincic et al., 2015). Hayashi (2000) states that the multi-criteria decision analysis in agriculture helps cope with the multitude of objectives and descriptive comments. Pavlovič et al. (2011) have developed a multifunctional decision making model called DEX-HOP for preliminary hop hybrid assessment. The research was done on common hop (Humulus lupulus, L.) since hop significantly contributes to the quality of flavour and aroma in beer. An overview of the use of multi-criteria decision analysis in the field of organic farming can be found in the study by Christensen et al. (2012).

The authors assert that the production and usage of organic products affected the decision problems, characterised by different goals, namely whether the consumer, producer or politician was the main decision maker. Rozman et al. (2013) developed a model of system dynamics for the development of organic farming, which would support the government's decision-making process - a case study in Slovenia. Dragincic et al. (2015) used the methods of Simple Additive Weighting (SAW), AHP and Dong's et al. Cardinal consensus model to study the most appropriate variety of organic table grapes, which would affect the final production performance.

The aim of the study is the development of technologic - simulation model for vegetable production in greenhouse and multi-criteria decision analysis for salad, growing peppers, salad cucumbers, pickling cucumbers, round and cherry tomato production. There are two emphasized goals: development of simulation model (i) and its application in combination with the DEX-i method and Analytical hierarchical process - AHP (Expert Choice (EC) software) on a presented vegetable production in greenhouse (ii). The research question that is followed in the paper is which the most suitable alternative by combining technological-economic simulation modelling and multi-criteria decision analysis in the cultivation of vegetables in greenhouse.

\section{Methodology}

The essential concept of our study refers to the economics of integrated and organic production of six types of market-attractive vegetables (salad, growing peppers, salad cucumbers, pickling cucumbers, round and cherry tomato) in greenhouse. For this purpose, the first research phase included the development of individual technological-economic simulation models with pertaining calculations of total costs.

These were practically acquired from the inventory of individual phases of the technological process of integrated and organic production of market-attractive vegetables in greenhouse. We are referring to the so called computer assisted deterministic technological-economic simulation models (Tamubula and Sinden, 2000). Multi-parameter decision-making, which is based on the decomposition of the main issue into smaller issues, was selected for the evaluation of production systems. The model is based on the DEX methodology (Bohanec et al., 2013) and the AHP analytical hierarchy process of organic and integrated vegetable production. The observed hierarchical problem structure include four main aspects, i.e criterion (the economic, developmental, technological and environmental criterion) which have an important effect on the individual vegetable production system in greenhouse.

\subsection{The development of technologi- cal-economic simulation models}

For the purposes an integrated technological-economic deterministic simulation model that assesses the economic feasibility of production (Figure 1) were developed. The system comprises of interrelated mathematical-functional relations between technological and economic variables.

By using designed individual models, the computer program calculates the technological parameters of a specific production, which forms the basis of the technological map. By calculating the total costs, data is automatically collected in a single developed simulation model and mathematical equations are performed which calculate specific economic parameters (revenues, financial result, break-even price and break-even point of production, cost price and the economic coefficient) depending on different input parameters (various inputs, prices, fertilizers, various products, areas, percentage of loss etc.). Model evaluated parameters represent the input data for the second phase of research work; development of a multi-criteria decision model based on the DEX method and the AHP analytical-hierarchy process of organic and integrated production of vegetables in greenhouse.

\subsection{Multi-criteria decision model}

The DEX and AHP method are based on the process of restructuring an issue into smaller and less challenging sub-issues; that is it is based on the decomposition of the 


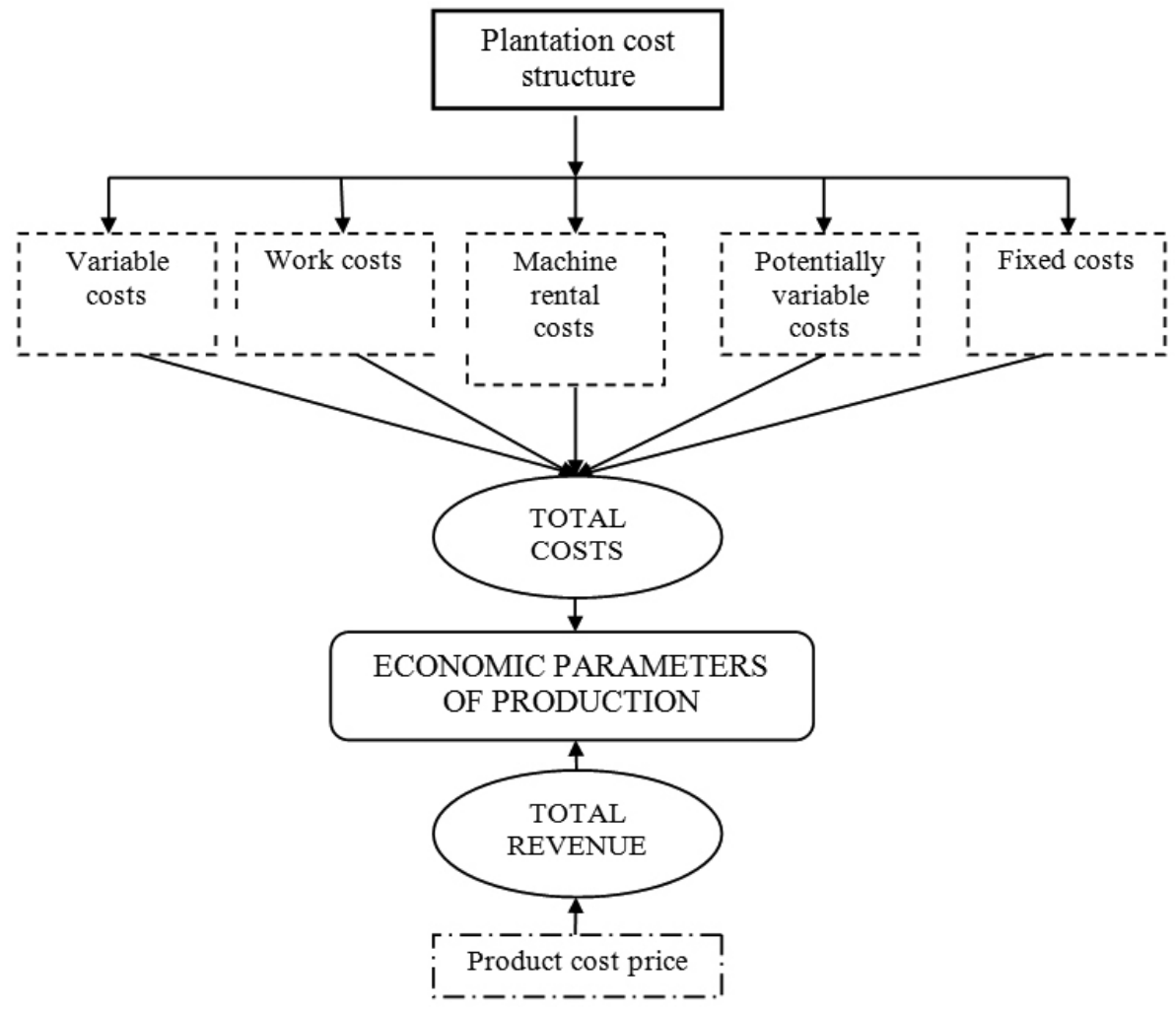

Figure 1: The structure of the developed simulation model

main issue in the form of a hierarchy, where the structure of hierarchy is identical in both models. The differences between methods occur in measurement scales and in the methods of combining the criteria into the final result. The main issue is structured as a hierarchy, while the sub-issues or the interim concepts are illustrated with variables which we interconnect with a structure.

The decision model for integrated and organic production of market-attractive vegetables in greenhouse is comprised of four main criteria on the primarily level and thirteen sub-criteria on the secondary level. The design of the decision model included a classical manual approach. The hierarchy of the decision model for integrated and organic production of six market-attractive vegetables in greenhouse is shown in Figure 2.

\section{Results and discussion}

\subsection{Results of the simulation model for integrated and organic vegetable pro- duction in greenhouse}

The simulation model was developed on the basis of technological-economic data collected during the individual phases of the technological process of integrated and organic vegetable production in greenhouse. The model analysis has been performed in a greenhouse of one hectare for each individual vegetable. The calculation of individual parameters have been performed with the Microsoft Office Excel 2007 package which represents an electronic table that enables editing, automatic calculation and analysis of data.

Using the developed specific model the computer program calculates the technological parameters of production which form the basis for the technological map with calculations of total costs (Figure 3). The developed model collects input data and performs mathematical equations which determine specific economic parameters (revenue, economic result, break-even price and point of production and the economic coefficient) depending on different input parameters (various inputs, prices, fertilizers, various products, areas, percentage of loss, etc.). All prices collected and included in the models are retail and wholesale prices with value added tax (VAT). To calculate the results we first had to gather the costs that occur during the year in the production of vegetables grown in an integrated and organic manner in greenhouse.

The total revenue was calculated by multiplying the expected amount of produce of each individual production with the sales price of the product that was set according to realistic expectations. 


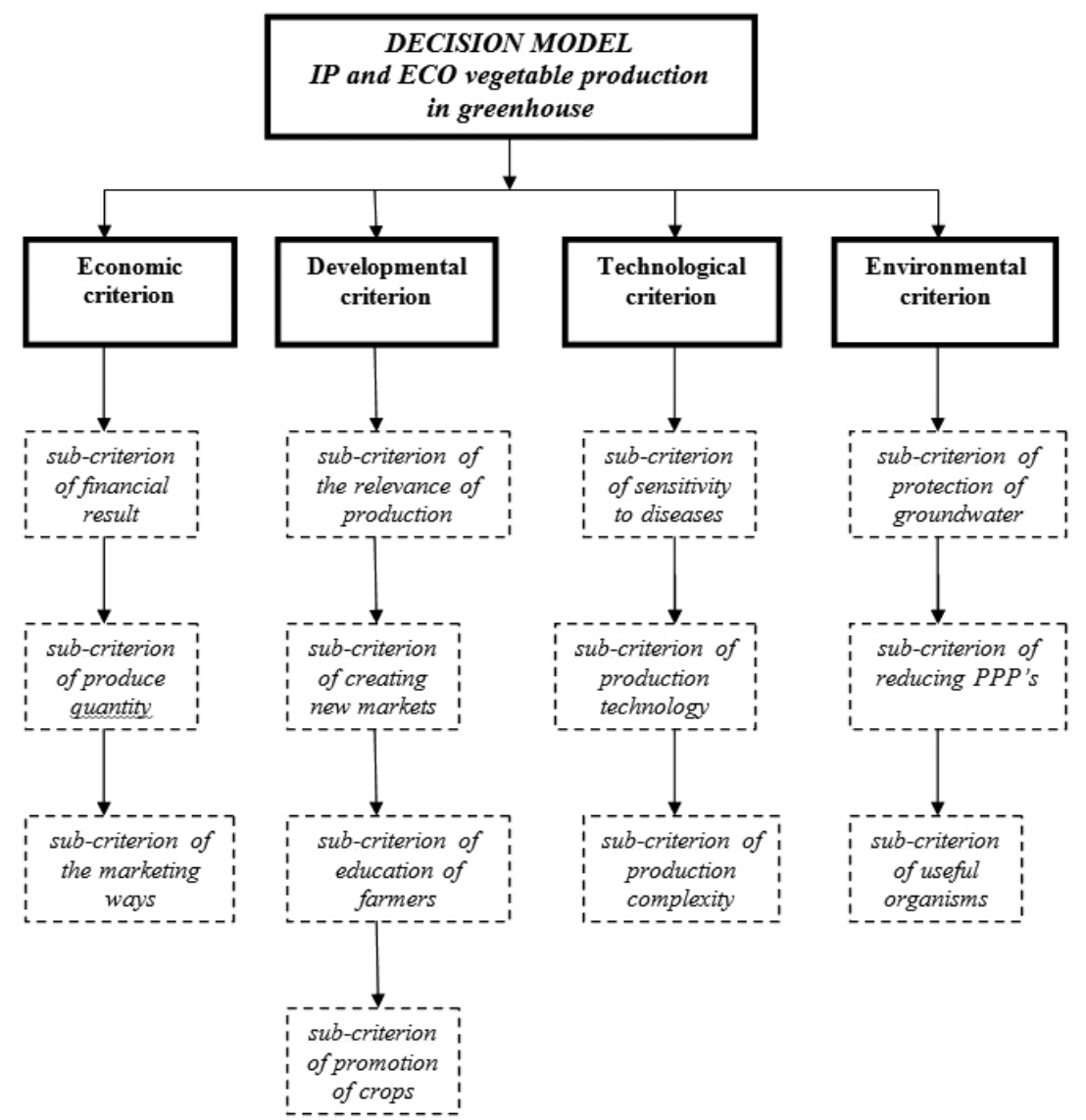

Figure 2: The hierarchy of the decision model for integrated and organic production of six market-attractive vegetables in greenhouse

\subsubsection{Economic analysis of integrated vegeta- ble production}

In presented case the produced vegetables (growing peppers - Bianca $F 1$, salad cucumbers - Darina $F 1$, pickling tcucumbers - Harmony F1, round tomato - Amaneta F1, cherry tomato - Sakura F1 and salad - Donertie F1) were grown in five greenhouses. The production has taken place on five hectares (greenhouse 1/1 ha, greenhouse 2/1 ha, greenhouse 3/1 ha, greenhouse $4 / 1$ ha, greenhouse $5 / 1$ ha). The integrated production has been carried out according to the Rules on integrated production of vegetables (MKGP, 2010).

As seen in Table 1, from economical point of view is the most suitable production of pickling cucumbers, followed by production of cherry and round tomato. Based on gained economic analysis is expected that ranking using both multi-criteria tool will be the same.

\subsubsection{Economic analysis of organic vegetable production}

Organic vegetables (growing peppers - Vedrana F1, salad cucumbers - Dinero F1, pickling cucumbers - Harmony $F 1$, round tomato - Rally F1, cherry tomato - Sakura F1 and salad - Noisette F1) were grown in five green houses. The production takes place on five hectares (greenhouse $1 / 1$ ha, greenhouse $2 / 1$ ha, greenhouse $3 / 1$ ha, greenhouse $4 / 1$ ha, greenhouse $5 / 1 \mathrm{ha}$ ). The organic production is carried out according to the Rules on organic production and processing of agricultural products and/or foods (MKGP, 2014).

Compared to integrated production the economy coefficients by organic vegetable production are lower. The ranking of business alternatives is not equal (Table 1 and 2). Salad cucumbers and cherry tomato assess the same value of economy coefficient. The reason are higher sale price and quantity production in integrated production. Production of salad is in both observed alternatives on the last place (relationship between sale and break - even 


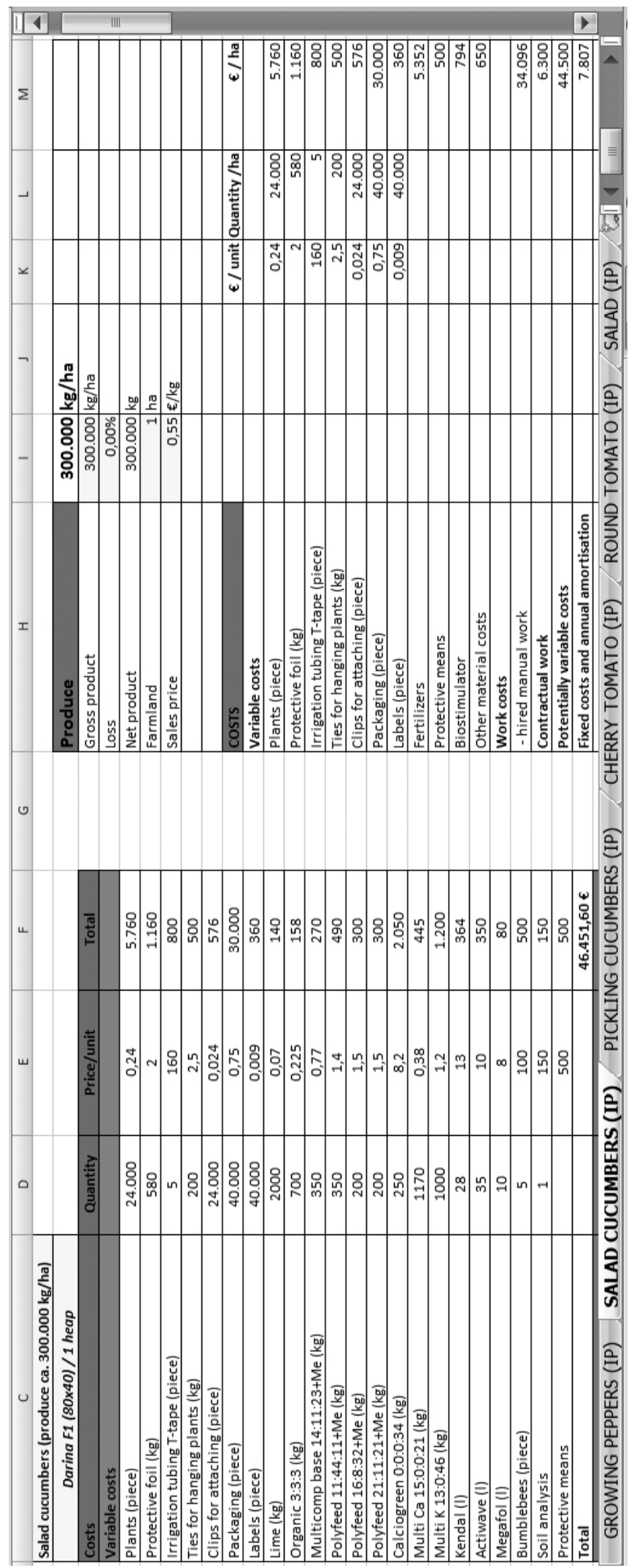

Figure 3: An excerpt from the calculation model for the integrated production of salad cucumbers in greenhouse 
Table 1: The economic analysis of integrated vegetable production

\begin{tabular}{|c|c|c|c|c|c|c|c|c|c|}
\hline & $\begin{array}{c}\text { Expected } \\
\text { produce } \\
(\mathrm{t} / \mathrm{ha})\end{array}$ & $\begin{array}{c}\text { Sales } \\
\text { price }(€ / \\
\mathrm{kg})\end{array}$ & $\begin{array}{c}\text { Total } \\
\text { cost }(€)\end{array}$ & $\begin{array}{c}\text { Revenue } \\
(€)\end{array}$ & $\begin{array}{c}\text { Financial } \\
\text { result } \\
(€)\end{array}$ & $\begin{array}{c}\text { Break-even } \\
\text { price of } \\
\text { production } \\
(€ / \mathrm{kg})\end{array}$ & $\begin{array}{c}\text { Break-even } \\
\text { point of } \\
\text { production } \\
(\mathrm{kg})\end{array}$ & $\begin{array}{c}\text { Cost price } \\
\text { with } \\
\text { subsidy } \\
(€ / \mathrm{kg})\end{array}$ & $\begin{array}{c}\text { Economy } \\
\text { coefficient }\end{array}$ \\
\hline $\begin{array}{c}\text { Growing } \\
\text { peppers }\end{array}$ & 150 & 0,85 & 106.219 & 127.500 & 21.281 & 0,71 & 124.963 & 0,71 & 1,20 \\
\hline $\begin{array}{c}\text { Salad } \\
\text { cucumbers }\end{array}$ & 300 & 0,55 & 139.155 & 165.000 & 25.845 & 0,46 & 253.009 & 0,46 & 1,19 \\
\hline $\begin{array}{c}\text { Pickling } \\
\text { cucumbers }\end{array}$ & 150 & 0,90 & 77.620 & 135.000 & 57.380 & 0,52 & 86.244 & 0,52 & 1,74 \\
\hline $\begin{array}{c}\text { Cherry } \\
\text { tomato }\end{array}$ & 170 & 1,15 & 128.282 & 195.500 & 67.218 & 0,75 & 111.549 & 0,76 & 1,52 \\
\hline $\begin{array}{c}\text { Round } \\
\text { tomato }\end{array}$ & 250 & 0,65 & 127.528 & 162.500 & 34.972 & 0,51 & 196.196 & 0,51 & 1,27 \\
\hline Salad & 60 & 0,90 & 46.266 & 54.000 & 7.734 & 0,77 & 51.407 & 0,78 & 1,17 \\
\hline
\end{tabular}

Table 2: The economic analysis of organic vegetable production

\begin{tabular}{|c|c|c|c|c|c|c|c|c|c|}
\hline & $\begin{array}{c}\text { Expected } \\
\text { produce (t/ } \\
\text { ha) }\end{array}$ & $\begin{array}{c}\text { Sales } \\
\text { price } \\
(€ / \mathrm{kg})\end{array}$ & $\begin{array}{c}\text { Total cost } \\
(€)\end{array}$ & Revenue & $\begin{array}{c}\text { Financial } \\
\text { result } \\
(€)\end{array}$ & $\begin{array}{c}\text { Break-even } \\
\text { price of } \\
\text { production } \\
(€ / \mathrm{kg})\end{array}$ & $\begin{array}{c}\text { Break-even } \\
\text { point of } \\
\text { production } \\
(\mathrm{kg})\end{array}$ & $\begin{array}{c}\text { Cost } \\
\text { price } \\
\text { with } \\
\text { subsidy } \\
(€ / \mathrm{kg})\end{array}$ & $\begin{array}{c}\text { Economy } \\
\text { coefficient }\end{array}$ \\
\hline $\begin{array}{c}\text { Growing } \\
\text { peppers }\end{array}$ & 110 & 1,00 & 101.178 & 110.000 & 8.822 & 0,92 & 101.178 & 0,93 \\
\hline $\begin{array}{c}\text { Salad cu- } \\
\text { cumbers }\end{array}$ & 200 & 0,75 & 122.768 & 150.000 & 27.232 & 0,61 & 163.691 & 0,62 \\
\hline $\begin{array}{c}\text { Pickling } \\
\text { cucumbers }\end{array}$ & 90 & 1,50 & 100.606 & 135.000 & 34.394 & 1,12 & 67.071 & 1,13 \\
\hline $\begin{array}{c}\text { Cherry } \\
\text { tomato }\end{array}$ & 120 & 1,20 & 118.137 & 144.000 & 25.863 & 0,98 & 98.447 & 0,99 \\
\hline $\begin{array}{c}\text { Round to- } \\
\text { mato }\end{array}$ & 150 & 0,90 & 114.106 & 135.000 & 20.894 & 0,76 & 126.784 & 0,77 \\
\hline Salad & 35 & 1,20 & 40.202 & 42.000 & 1.798 & 1,15 & 33.502 & 1,18 & 1,22 \\
\hline
\end{tabular}

price). In the next chapter it is explained and presented the assessments of primary criteria and secondary sub-criteria of the developed multi-criteria decision model DEX and the AHP of individual vegetable productions alternatives in greenhouse.

\subsection{Results of the DEX multi-criteria model}

\subsubsection{Results of the DEX multi-criteria model for integrated vegetable production}

According to the primary level of hierarchy of the DEX multi-criteria decision model, the assessment of integrat- ed vegetable production in greenhouses demonstrated that the best rated criterion was the "developmental criteria" (evaluated as excellent) and the "economic criteria" (evaluated as excellent) in the production of round tomatoes, and the "technological criteria" (evaluated as excellent) in the production of salad. The worst assessment was given to the "developmental criteria" (evaluated as bad) in the production of pickling cucumbers (Table 3 ).

The final multi-criteria assessment of integrated vegetable production in greenhouse (Table 3 ) demonstrates that the production of growing peppers, salad cucumbers, cherry tomato, round tomato and salad is evaluated as good, while the production of pickling cucumbers is rated as $a c$ ceptable. 
Table 3: The assessment of integrated vegetable production with the DEXi tool

\begin{tabular}{|c|c|c|c|c|c|c|}
\hline Option & $\begin{array}{l}\text { GROWING } \\
\text { PEPPERS }\end{array}$ & $\begin{array}{l}\text { SALAD CU- } \\
\text { CUMBERS }\end{array}$ & $\begin{array}{l}\text { PICKLING } \\
\text { CUCUM- } \\
\text { BERS }\end{array}$ & $\begin{array}{l}\text { CHERRY } \\
\text { TOMATO }\end{array}$ & $\begin{array}{l}\text { ROUND } \\
\text { TOMATO }\end{array}$ & SALAD \\
\hline $\begin{array}{l}\text { ASSESSMENT OF INTE- } \\
\text { GRATED VEGETABLE } \\
\text { PRODUCTION }\end{array}$ & good & good & acceptable & good & good & good \\
\hline ECONOMIC CRITERION & average & average & average & average & excellent & average \\
\hline Financial result of production & average & average & excellent & excellent & excellent & average \\
\hline Produced quantity & good & high & good & good & high & average \\
\hline Market ways & average & excellent & average & bad & excellent & average \\
\hline DEVELOPMENT CRITERION & average & average & bad & average & excellent & excellent \\
\hline Relevance of production & relevant & $\begin{array}{l}\text { potentially } \\
\text { interesting }\end{array}$ & $\begin{array}{l}\text { potentially } \\
\text { interesting }\end{array}$ & $\begin{array}{l}\text { potentially } \\
\text { interesting }\end{array}$ & $\begin{array}{l}\text { very } \\
\text { relevant }\end{array}$ & very relevant \\
\hline $\begin{array}{c}\text { Potential for creating } \\
\text { new markets }\end{array}$ & average & excellent & average & bad & excellent & excellent \\
\hline Education of farmers & average & average & bad & bad & average & good \\
\hline Promotion of crops & low & low & low & good & good & good \\
\hline $\begin{array}{c}\text { TECHNOLOGICAL } \\
\text { CRITERION }\end{array}$ & average & average & average & average & average & excellent \\
\hline $\begin{array}{l}\text { Sensitivity to diseases and } \\
\text { vermin's }\end{array}$ & average & average & average & high & low & low \\
\hline $\begin{array}{l}\text { Knowing the production } \\
\text { technology }\end{array}$ & average & average & average & excellent & excellent & excellent \\
\hline $\begin{array}{l}\text { Difficulty of the production } \\
\text { technology }\end{array}$ & high & average & average & high & high & low \\
\hline $\begin{array}{l}\text { ENVIROMENTAL } \\
\text { CRITERION }\end{array}$ & average & average & average & average & average & average \\
\hline Protection of groundwater & average & average & average & average & average & bad \\
\hline $\begin{array}{l}\text { Reduction of the use } \\
\text { phytopharmaceuticals }\end{array}$ & average & average & average & average & average & high \\
\hline $\begin{array}{c}\text { Possibilities of obtaining } \\
\text { useful organism }\end{array}$ & average & good & good & good & good & bad \\
\hline
\end{tabular}

\subsubsection{Results of the DEX multi-criteria model for organic vegetable production}

For organic vegetable production in greenhouses the best rated criteria proved to be the "developmental criteria" (evaluated as excellent) in the production of all types of vegetables, "environmental criteria" (evaluated as good) in all vegetables except salad and the "economic criteria" (evaluated as excellent) in the production of salad cucumbers. The worst assessment was given to the "technological criteria" (evaluated as $b a d$ ) in the production of cherry tomatoes and the "economic criterion" (evaluated as bad) in the production of salad (Table 4).

Further, the final assessment of organic vegetable production in greenhouses (Table 4) demonstrated that the production of growing peppers, salad cucumbers, pickling cucumbers and round tomatoes is evaluated as good, while the production of cherry tomatoes and salad is evaluated as acceptable.

\subsection{Results of the AHP multi-criteria model}

\subsubsection{Results of the AHP multi-criteria model for integrated vegetable production}

The final assessment of integrated vegetable production in greenhouse (Figure 3) has demonstrated that the production of salad was evaluated as the best $(\mathrm{EC}=0.253)$, followed by the production of round tomato $(\mathrm{EC}=0.220)$, cherry tomato $(\mathrm{EC}=0.163)$, growing peppers $(\mathrm{EC}=$ $0.125)$, salad cucumbers $(\mathrm{EC}=0,121)$. 
As expected from the DEXi model results, the lowest evaluation was given to the production of pickling cucumbers $(\mathrm{EC}=0.119)$.

\subsubsection{Results of the AHP multi-criteria model for organic vegetable production}

The production of organic pickling cucumbers was evaluated as the best $(\mathrm{EC}=0.215)$, followed by the production of growing peppers $(\mathrm{EC}=0.201)$, round tomato $(\mathrm{EC}=$ $0.195)$, salad $(E C=0.179)$, salad cucumbers $(E C=0.112)$. Ats seen in previous figure, the lowest evaluation was given to the production of cherry tomato $(\mathrm{EC}=0.098)$. However, as seen previous results there exist the differences by economical and multi - criteria assessment of vegetable production.

\section{Conclusions}

For the purposes of our study we have developed an integrated technological-economic deterministic model, enabling the assessment of economic viability of six market-attractive vegetables (salad, growing peppers, salad cucumbers, pickling cucumbers, round and cherry tomato), produced in an integrated and organic manner in greenhouse. To help assess the production of vegetables in greenhouse we have developed a model based on the DEX method and the analytical hierarchy process (AHP) of

Table 4: The assessment of organic vegetable production with the DEXi tool

\begin{tabular}{|c|c|c|c|c|c|c|}
\hline Option & $\begin{array}{l}\text { GROWING } \\
\text { PEPPERS }\end{array}$ & $\begin{array}{l}\text { SALAD CU- } \\
\text { CUMBERS }\end{array}$ & $\begin{array}{l}\text { PICKLING CU- } \\
\text { CUMBERS }\end{array}$ & $\begin{array}{l}\text { CHERRY } \\
\text { TOMATO }\end{array}$ & $\begin{array}{l}\text { ROUND } \\
\text { TOMATO }\end{array}$ & SALAD \\
\hline $\begin{array}{l}\text { ASSESSMENT OF IN- } \\
\text { TEGRATED VEGETA- } \\
\text { BLE PRODUCTION }\end{array}$ & good & good & good & acceptable & good & acceptable \\
\hline $\begin{array}{c}\text { ECONOMIC CRITE- } \\
\text { RION }\end{array}$ & average & & average & average & average & bad \\
\hline $\begin{array}{c}\text { Financial result of pro- } \\
\text { duction }\end{array}$ & average & excellent & excellent & excellent & average & bad \\
\hline Produced quantity & good & high & good & good & high & low \\
\hline Market ways & excellent & excellent & excellent & average & excellent & average \\
\hline $\begin{array}{l}\text { DEVELOPMENT CRI- } \\
\text { TERION }\end{array}$ & excellent & excellent & excellent & excellent & excellent & excellent \\
\hline Relevance of production & Very relevant & relevant & Very relevant & relevant & $\begin{array}{l}\text { Very rele- } \\
\text { vant }\end{array}$ & relevant \\
\hline $\begin{array}{l}\text { Potential for creating new } \\
\text { markets }\end{array}$ & excellent & average & excellent & average & excellent & average \\
\hline Education of farmers & good & average & average & average & good & good \\
\hline Promotion of crops & high & good & high & good & high & good \\
\hline $\begin{array}{l}\text { TECHNOLOGICAL } \\
\text { CRITERION }\end{array}$ & average & average & average & bad & average & average \\
\hline $\begin{array}{l}\text { Sensitivity to diseases } \\
\text { and vermin's }\end{array}$ & average & average & average & high & average & low \\
\hline $\begin{array}{l}\text { Knowing the production } \\
\text { technology }\end{array}$ & average & average & average & average & average & average \\
\hline $\begin{array}{l}\text { Difficulty of the produc- } \\
\text { tion technology }\end{array}$ & high & high & high & high & High & average \\
\hline $\begin{array}{c}\text { ENVIROMENTAL CRI- } \\
\text { TERION }\end{array}$ & good & good & good & good & Good & average \\
\hline Protection of groundwater & high & high & high & high & high & Good \\
\hline $\begin{array}{l}\text { Reduction of the use } \\
\text { phytopharmaceuticals }\end{array}$ & high & high & high & high & high & High \\
\hline $\begin{array}{c}\text { Possibilities of obtaining } \\
\text { useful organism }\end{array}$ & good & good & good & good & good & average \\
\hline
\end{tabular}


organic and integrated vegetable production. The assessment results demonstrate that both methods of producing market-attractive vegetables in greenhouse (integrated and organic production) are variable.

In the case of integrated production the multi-criteria decision analysis assessment $\mathrm{EC}=0.253$ and DEXi evaluation $=$ good showed that salad $($ Donertie F1) proved to be the best possible alternative. In the case of organic production the multi-criteria decision analysis assessment EC $=0.215$ and DEXi evaluation $=$ good showed that pickling cucumbers (Harmony F1) are the best alternative. In integrated vegetable production, the worst alternative proved to be the production of pickling cucumbers (Harmony F1), which received the multi-criteria decision analysis assessment $\mathrm{EC}=0.119$ and DEXi evaluation = acceptable. In organic production, the worst alternative proved to be cherry tomato (Sakura F1), which received the multi-criteria decision analysis assessment $\mathrm{EC}=0.098$ and DEXi evaluation $=$ acceptable . Ranking alternatives (vegetables) with multi-criteria decision models DEX and AHP is basically the same.
Further, unlike the DEXi decision model, where the criteria/sub-criteria are evaluated as the same in different alternatives, the Expert Choice Model also demonstrates more detailed differences in the calculation of total priority of a specific criterion/sub-criterion in individual alternatives. Therefore, ranking individual alternatives by using the AHP multi-criteria model is more accurate and makes it easier for the user to decide on an appropriate alternative. On the other site, the data availability required for used methodological approaches for defined alternatives can be a serious limitation in the planning process. However, the integrated system takes into consideration different independent objectives and enables ranking of different business alternatives. Further research could be made in combinations with the AHP resource allocation theory, where calculated priorities could be used for optimal allocation of business entrepreneurship resources at constrained investments; naturally, the AHP hierarchy should be changed correspondingly. The decision model should be also interrelated to the marketing informatio system (marketing attribute).
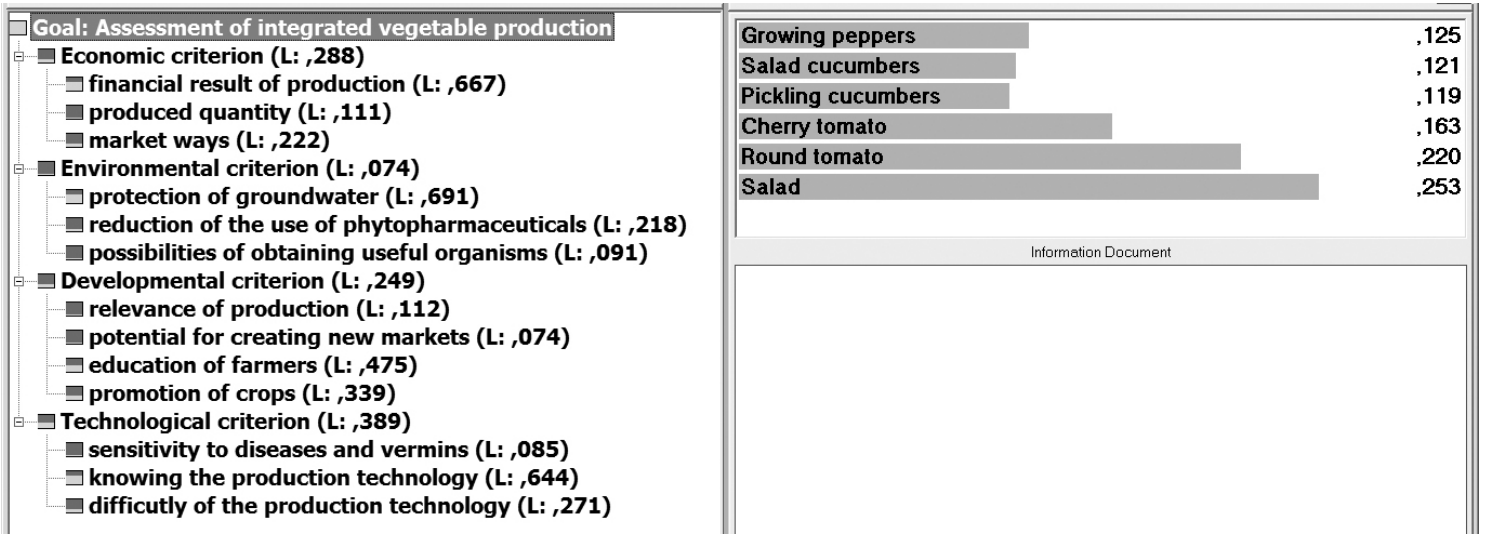

Figure 3: Final assessment of integrated vegetable production with the AHP tool
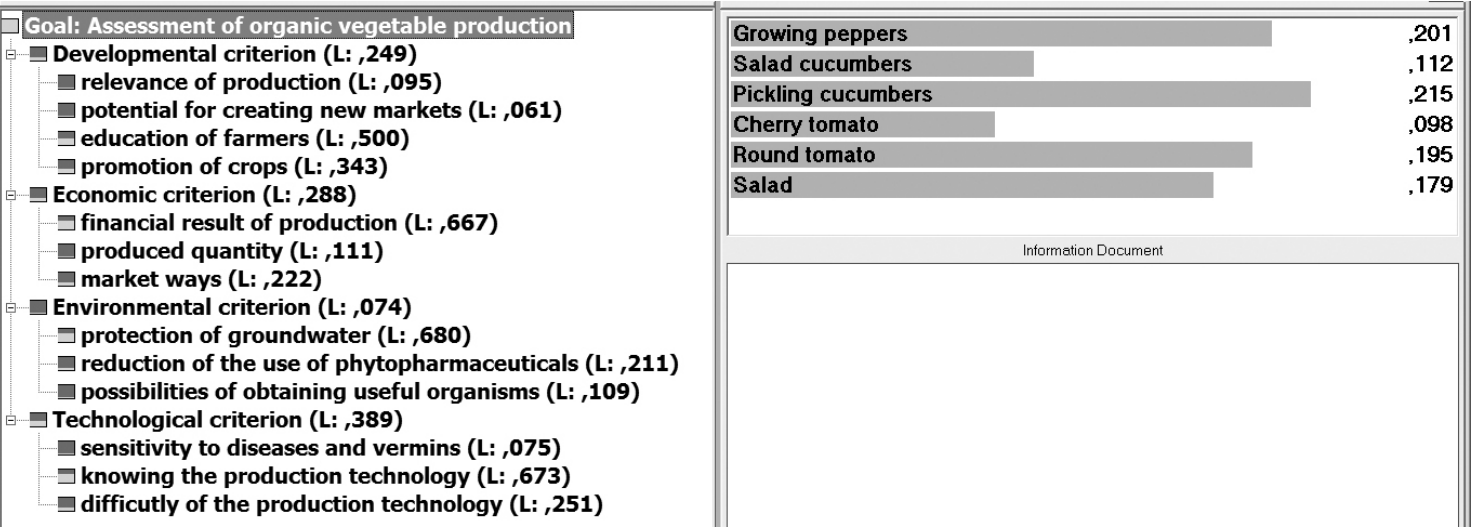

Figure 4: Final assessment of organic vegetable production with the AHP tool 


\section{References}

Bohanec M., Rajkovič V., Bratko I., Zupan B. \& Žnidaršič, M. (2013). DEX Methodology: Three Decades of Qualitative Multiattribute Modelling. Informatica, 37, 49-54. http://kt.ijs.si/MarkoBohanec/pub/2013_Informatica_DEX.pdf

Bohanec M., Messéan A., Scatasta S., Angevin F., Griffiths B., Henning Krogh P., Žnidaršič M. \& Džeroski S. (2008). A qualitative multi-attribute model for economic and ecological assessment of genetically modified crops. Ecological Modelling, 215 (1-3), 247-261, http://dx.doi.org/10.1016/j.ecolmodel.2008.02.016

Cardín-Pedrosa M. \& Alvarez-López C.J. (2012). Model for decision-making in agricultural production planning. Computers and Electronics in Agriculture, 86, 131-139, http://dx.doi.org/10.1016/j.compag.2011.12.004

Christensen, T., Olsen, S.B., Dubgaard, A. \& Kærgård, N. (2012). Organic Farming and Multicriteria Decisions: An Economic Survey. Institute of Food and Resource Economics, University of Copenhagen, p. 1-10.

Dragincic J., Korac N. \& Blagojevic B. (2015). Group multi-criteria decision making (GMCDM) approach for selecting the most suitable table grape variety intended for organic viticulture. Computers and Electronics in Agriculture, 111, 194-202, http://dx.doi. org/10.1016/j.compag.2014.12.023

Gómez-Limón J.A., Riesgo L. \& Arriaza M. (2004). Multi-criteria analysis of input use in agriculture. Agricultural Systems, 91 (1-2), 1-28, http://dx.doi. org/10.1111/j.1477-9552.2004.tb00114.x

Hayashi K. (2000). Multicriteria analysis for agricultural resource management: a critical survey and future perspectives. European Journal of Operational Research, 122 (2), 486-500, http://dx.doi.org/10.1016/S03772217(99)00249-0

Jayakumar S. \& Hari Ganesh A. (2012). Fuzzy multi criteria group decision making (Mcgdm) approach for variety selection in rice farming. Aust. J. Basic Appl. Sci., 6 (12), 308-318.

Klajič M., Bernik I. \& Škraba A. (2000). Simulation Approach to Decision assessment in Enterprises. Simulation,C 75(4): 199-210, http://dx.doi. org/10.1177/003754970007500402

Latinopoulos D. (2009). Multicriteria decision-making for efficient water and land resources allocation in irrigated agriculture. Environ. Dev. Sustain., 11 (2), 329-343, http://dx.doi.org/10.1007/s10668-007-9115-2

Mohamed K.A., Idris A.E., Mohammed H.I. \& Adam K.A.O. (2012). Ranking rice (Oryza sativa L.) genotypes using multi-criteria decision making, correlation and path coefficient analysis. Brit. Biotechnol. J., 2 (4), 211-228, http://dx.doi.org/10.9734/BBJ/2012/1821

Ministrstvo za kmetijstvo gozdarstvo in prehrano (MKGP).
(2014). Pravilnik o ekološki pridelavi in predelavi kmetijskih pridelkov oziroma živil. Ljubljana: Minister za kmetijstvo gozdarstvo in prehrano [Ministry of Agriculture, Forestry and Food (MAFF). (2014). Rules on organic production and processing of agricultural products and foodstuffs. Ljubljana: Minister of Agriculture, Forestry and Food].

Ministrstvo za kmetijstvo gozdarstvo in prehrano (MKGP). (2010). Pravilnik o integrirani pridelavi zelenjave. Ljubljana: Minister za kmetijstvo gozdarstvo in prehrano [Ministry of Agriculture, Forestry and Food (MAFF). (2010). Rules on integrated production of vegetables. Ljubljana: Minister of Agriculture, Forestry and Food].

Parra-López C., Calatrava-Requena J. \& de-HaroGiménez T. (2007). A multi-criteria evaluation of the environmental performances of conventional, organic and integrated olive-growing systems in the south of Spain based on experts' knowledge. Renew. Agr. Food Syst., 22(3), 189-203, http://dx.doi.org/10.1017/ $\underline{\mathrm{S} 1742170507001731}$

Pavlovič M., Čerenak A., Pavlovič V., Rozman Č., Pažek K. \& Bohanec M. (2011). Development of DEX-HOP multi-attribute decision for preliminary hop hybrids assessment. Computers and Electronics in Agriculture, 75, 181-189, http://dx.doi.org/10.1016/j.compag.2010.11.002

Riesgo L. \& Gomez-Limon J.A. (2006). Multi-criteria policy scenario analysis for public regulation of irrigated agriculture. Agricultural Systems, 91(1-2), 1-28, http://dx.doi.org/10.1016/j.agsy.2006.01.005

Rozman Č., Škraba A., Pažek K. \& Kljajić M. (2014). The development of sugar beet production and processing simulation model: a system dynamics approach to support decision-making processes. Organizacija, 47(2), 99-105, http://organizacija.fov.uni-mb.si/index.php/ organizacija/article/view/563

Rozman Č., Pažek K., Kljajić M., Bavec M., Turk J., Bavec F., Kofjač D. \& Škraba A. (2013). The dynamic simulation of organic farming development scenarios - A case study in Slovenia. Computers and Electronics in Agriculture, 96, 163-172, http://dx.doi.org/10.1016/j. compag.2013.05.005

Škraba A., Kljajič M., \& Leskovar R. (2003). Group exploration of system dynamics models - is there a place for a feedback loop in the decision process? System Dynamics Review, 19(3), 243-263.

Tamubula I. \& Sinden J.A. (2000). Sustainability and Economic Efficiency of Agroforestry Systems in Embu Distict, Kenya: An Application of Environmental Modelling. Environmental Modelling and Software, 15(1), 13-21. 
Silvo Pozderec is a PhD student of Agricultural Economics at Faculty of Agriculture and Life Sciences at University of Maribor. His research priorities are technological-economic simulation modelling and multi-parameter decision modelling in agriculture.

Martina Bavec is full professor of vegetable and field crops and organic agriculture at the University of Maribor, Slovenia. She has been an advisor for vegetable production and organic farming, as well as the main supporter for establishing a national inspection and certification body for organic agriculture. She has led many national and international projects, edited the main national book about organic agriculture, and authored and co-authored 43 research papers, and numerous professional papers. She is a very active presenter of organic agriculture in the community and a key representative of the BSC, MSc, and PhD study programs of organic agriculture at the university where she teaches. She is the co-author of a book "Organic production and Use of Alternative Crops" published by Taylor and Francis CRC Press. From March 2012 to July 2013 she worked on Ministry of Agriculture and the Environment as general Director of Directorate for agriculture being responsible beside daily work also for preparation of draft for Rural development program and decisions basis for pillar I.

Črtomir Rozman achieved his Ph.D. at University of Maribor, Faculty of Agriculture. He is active as Full Professor for Farm management in the Department for Agriculture Economics and Rural Development (Faculty of Agriculture and Life Sciences, University of Maribor). His research includes development of decision support systems for farm management (simulation modeling, multi-criteria decision analysis, machine learning) and economics of agricultural production. He is also involved in teaching activities as Head of Department and as thesis supervisor at post graduate study programs and multiple national and international research projects. He is author or coauthor of 67 scientific papers including 28 papers in journals with impact factor.

Jožef Vinčec is a PhD student of Agricultural Economics at Faculty of Agriculture and Life Sciences at University of Maribor. His research priorities are Operational research in agriculture and simulation modelling.

Karmen Pažek achieved her Ph.D. at University of Maribor, Faculty of Agriculture in 2006. She is active as Associated Professor for Farm management in the Department for Agriculture Economics and Rural Development on Faculty of Agriculture and Life Sciences, University of Maribor. Her research includes development of decision support tools and systems for farm management (simulation modeling, multi-criteria decision analysis, option models) and economics of agricultural production. She is involved in teaching activities as thesis supervisor at postgraduate study programs and involved in national and international research projects. She is author or coauthor of 45 scientific papers including 20 papers in journals with impact factor. 